\title{
VISUAL-BASED AND VERBAL-BASED MATERIALS IN TEACHING WRITING TO STUDENTS WITH DIFFERENT LEARNING STYLES
}

\author{
Fiki Setiawan ${ }^{1}$, Taiman ${ }^{2}$ \\ ${ }^{1,2}$ Akademi Analis Kesehatan An Nasher, Kaliwadas, Kecamatan Sumber, Cirebon, \\ Jawa Barat 4561, pikipikipiki24@gmail.com¹, taimantea@gmail.com²
}

Diterima 29 September 2020, disetujui 05 Oktober 2020, diterbitkan 20 Oktober 2020

Pengutipan: Setiawan, F, Taiman (2020). Visual-Based And Verbal-Based Materials In Teaching Writing to Students With Different Learning Styles. Gema Wiralodra, Vol 11, No 2, Hal 233-249, Oktober 2020

\begin{abstract}
This study was aimed to investigate the implementation of visual-based and verbal-based materials in teaching writing to students with different learning styles. This study employed a quasi-experimental design with a $2 \times 2$ factorial design conducted in the health analyst academy Indonesia. There were two experimental groups involved. Visual-based and verbal-based materials had been used as teaching media for collecting the data. The observation was also conducted to support the data findings. The research findings indicated that both visual-based and verbal-based materials were useful to be used in teaching writing to students with different learning styles. However, the findings indicated that visual-based material was more effective to be used in both spatial and linguistic learning styles students. The result of observation also showed that students considered visual-based material to be more interactive and exciting. Students' learning styles proved to have a significant influence on teaching materials, primarily when verbal-based material was implemented. The visual-based materials have a substantial impact on the students' writing ability. It could be concluded that visual-based material was adequate for the students with a spatial learning style, while verbal-based material was sufficient to the students with a linguistic learning style in teaching writing.
\end{abstract}

Keywords: learning style; visual-based material; verbal-based material

\section{INTRODUCTION}

Writing as a productive skill is considered to be more difficult than any other productive skill. Students face difficulties and commit errors in many different writing aspects. They were unable to determine the right words and sufficient ideas to build the text and still confused about how they started to write a paragraph. Students feel the anxiety to express their opinions in writing. They do not know how to start writing, how to combine the idea into a sentence. Ontario (2005: 13) states that writing is a powerful instrument for students, which is used to express their thoughts, feelings, and judgments about what they have read, seen, or experienced. By writing, the students convey their needs, deliver their ideas, and express their thoughts to others. The students always face difficulties in exploring ideas and they also have limitation of vocabularies and grammar. In responding to this case, it is clear that the students' writing skill 
should be improved in some ways, for example through the use of media that are effective to arouse the students' motivation and interest through their learning styles. These problems are like problems in learning writing English in foreign language classroom.

The students need learning materials to help them in the writing process. Curriculum justifies the materials that can be used for teaching language skills, so teachers should be aware of developing activities and preparing materials in the classroom. In this research, visual-based and verbal-based were used to help the learner with their characteristic. Every student comes to the classroom with a set of characteristics and behaviors, which makes them unique, and it will affect their academics. In this study, teachers need to verify their teaching techniques to accommodate the different learning styles that the students have.

Learning styles could be defined as the different learning methods which are taken by students in understanding new information. Students' learning style preferences have been a major concern for some research. The VARK system categorizes learners into four styles: Visual, Auditory, Read Write, and Kinesthetic (Fleming, 2013:1). There are two types of learning styles that had used in this study related to the topic to know the effectiveness of visual-based and verbal-based materials in teaching writing to students with different learning styles. Those learning styles are spatial (visual) and linguistic (verbal) learning styles.

Soleimani (2014), Macwan (2015), and Bagheri (2015) had conducted a study of visual and verbal materials in the teaching of English writing. Generally, the results of their research stated that by implementing visual-based materials, the students were actively involved in the teaching-learning process. These articles are an effort that language learning becomes fun and an activity to look forward to if visual aids like clips, episodes, documentaries, films are part of the language learning process. Visual aids demand complete attention. It may also enhance the imagination of the students, and that may lead to skills like critical thinking, debates, and Group Discussions. Language learning requires listening to language attentively. Then, the previous study was about learning style that was conducted by Amir (2010), Hussain (2013), Singh (2016), and Vizeshfar (2018). 
The finding of the previous studies is clearly stated that the study suggests a positive correlation between student learning style and teaching. On the other hand, this study was different from the previous research above. This research focused on the interaction between material aids and students' learning styles. In conclusion, visual-based and verbal based materials can influence students' learning outcomes. Thus, in this study, the researchers tried to conduct the research about visual-based and verbal based materials, especially to teach writing analytical exposition text to the students with different learning styles. Analytical exposition belongs to academic writing. Academic writing in both foreign and native languages has long been known as the most challenging skill to master, particularly for EFL students.

\section{LITERATURE REVIEW}

Visual materials cover the whole range of non-verbal and non-auditory materials. They encompass a wide range of forms: photographs, cinema, and video films, videotapes, paintings, drawings, prints, designs, three-dimensional art such as sculpture and architecture. They may or may not be representational, and some may include writing or printing. Some can be categorized as fine art, others as the documentary record. The visual-based materials support the students in that matter, as they serve as metal scaffolds for the students and help teachers to correlate and coordinate accurate concepts making the learning more concrete. It can be said that visual-based material can help the teacher support the students in the classroom's teaching and learning process.

Hyland (2003: 11) defines that writing is among the essential skills that second language students need to develop, and the ability to teach writing is central to the expertise of a well-trained language teacher. Second, Nunan (2003: 88) defines that writing is the process of thinking to invent ideas, thinking about how to express into good writing, and arranging the ideas into statements and paragraphs.

Fardon (2013) states that learning style as a stable preference used by individuals to effectively organize, then process and develop their understanding of any learning challenge, task, or situation, thus adding an element of "stability" 
in his definition. The consensus here is that there are many learning styles (Fayombo, 2015: 47). Furthermore, Gilakjani (2012: 109) mentioned that learning style is vital for many reasons; however, there are three vital ones. First of all, people's learning styles will vary because everyone is different from one another, naturally. Secondly, it offers the opportunity to teach by using a wide range of methods effectively. Sticking to just one model, unthinkingly, will create a monotonous learning environment, so not everyone will enjoy the lesson. In other words, learning and teaching will be just words and not rooted in reality. Thirdly, we can manage many things in education and communication if we recognize the groups we are called to.

\section{RESEARCH METHOD}

This research is quantitative research, which tried to find a significant result about the use of one teaching technique for one experimental group. This research has two experimental groups with different teaching techniques. According to Muijs (2004:1), "Quantitative research is explaining phenomena by collecting numerical data that are analyzed using a mathematically based method (in particular statistics)."

This research was used 2X2 factorial design by Fraenkel \& Wallen (2005), elaboration of single-variable experimental design to permit investigation of two or more variables, at least one of which is manipulated by the researcher. There were first-grade students of Health Analyst Academy in English as a second language classroom in the academic year of 2019/2020. Purposive sampling technique applied to gain a sample of the study. Purposive sampling is chosen because the entire population is divided into groups or clusters and a purposive sample of this cluster selected. Two classes were chosen as experimental groups 1 and 2. The first group had been taught by using picture series and video as visualbased material, while the second group had been taught by using analytical exposition essay texts as verbal-based material. Both group be given a pre-test and post-test. The experimental group treated to apply visual-based and verbal-based material for eight meetings continuously. This research was used numerical data and analyzed using numerical comparisons and statistical packages for social science. The questionnaire was used in this research adopted to form the modality 
learning channel preference questionnaire by O'Brien (1990). Thus, the researcher could classify the students into spatial and linguistic learning styles. After collecting the data, the researcher analyzed the students' result of pre-test and post-test by using t-test was used to test the effect of teaching writing by using visual-based and verbal-based materials to students with spatial and linguistic learning style. At the same time, Analysis of variance test was used to check the relationship between variables that differ from one another.

\section{FINDING AND DISCUSSION}

\section{Finding}

The purpose of the research was to know the effectiveness of visual-based material compared with verbal-based material in teaching writing analytical exposition text to the students with the spatial and linguistic learning style of firstgrade students in the health analyst academy. In this study, there were two groups, namely the first experimental group, conducted with visual-based material, and the second experimental group, done with verbal-based material. This section presents the discussion of the whole results of the study. The statistical analysis was used to answer research questions and hypothesis tests. Before conducting the treatment, two tryouts were initiated to describe the validity and reliability of the test. Both participation questionnaires and writing tests were conducted in the tryout. The result shows that all of the items in the questionnaire were valid and reliable. Meanwhile, the result of the writing test try out was valid and reliable.

I used a learning style questionnaire for both experimental groups before I gave the pre-test and the treatments. The questionnaire was given to know the students' learning styles, whether they have a spatial learning style or a linguistic learning style, by filling the form. After dividing the class into two groups, experiment class one and experiment class two, the students got the pre-test. Here the pre-test was used to determine whether the writing ability of both classes was the same. The students also should answer the questionnaire to know their learning style. After gathering the learning styles questionnaire, I analyzed the forms to know the students' learning styles before giving them some treatments after giving the pre-test. According to the result, it was found that total students in visual-based class and verbal-based class were the same. Furthermore, there were 
14 students with a spatial learning style and 12 students with a linguistic learning style in visual-based material class. In verbal-based material class, there were 15 students with a spatial learning style and 8 students with a linguistic learning style.

After getting the pre-test, the students got the treatment. Experiment class one got the treatment by using visual-based material, and experiment class two got the treatment by using verbal-based material. After the treatment had been given to the students, the researcher gave a post-test. The result of pre-test could be seen in the following tables.

Table 1 Pre-test score

\begin{tabular}{cccc}
\hline Pre-test & Min. & Max. & Mean \\
\hline Group visual-based spatial & 62.75 & 76.75 & 70.39 \\
Group visual-based linguistic & 53 & 67.25 & 62.02 \\
Group verbal-based spatial & 60.75 & 84.5 & 70.17 \\
Group verbal-based linguistic & 61.50 & 83.75 & 70.78 \\
\hline
\end{tabular}

According to table 1. it could be concluded that the students from both the experimental group showed only a slight difference in the writing score of the pretest. The difference in the mean score of students with spatial learning styles in both experimental classes was 0.22 points, where the mean score in visual-based class was higher than the verbal-based group. Dealing with the highest and lowest score of pre-test in both experimental classes with spatial learning style students, the highest students' score in visual-based class was 76.75 while in verbal-based class was 84.5 Meanwhile, the lowest score of pre-test in visual-based class was 62.75 and in verbal-based class was 60.75 .

Dealing with the pre-test scores of students with linguistic learning style students in both experimental classes, the difference in mean students' scores of pre-test was 8.7 points, where the mean score in verbal-based class was higher than visual-based class. From the highest and lowest scores of pre-tests in both experimental classes with linguistic learning style students, the highest students' score in visual-based class was 67.25 while in verbal-based class was 83.75. 
Meanwhile, the lowest score of pre-test in visual-based class was 53 and in verbal-based class was 61.50 .

After conducting a pre-test for both experimental classes, the different treatments were given. The experimental class one was given picture series as visual-based material of teaching writing recount text while the other one was given essay recount text as verbal-based material. Both materials require the students' engagement in participating during the treatments. The main difference between those learning materials is the role of the teacher and the student. In visual-based class, the teacher is positioned as a facilitator while in a verbal-based material class. Here, the teacher takes as an actor in the teaching and learning process. The students were guided at each stage of the writing process. In visualbased class, group discussion is the central core of the learning process until they can produce their written works independently.

Moreover, the group discussion in visual-based class worked well. The students discussed the materials or tasks given by the teacher together after they shared and finished the written work project. It stimulated the students' learning style of producing their best products. Meanwhile, in verbal-based class, it took more effort when giving treatments for the students. Researchers had to help every individual to produce their writing. It was more challenging to make the process of teaching and learning work well. Based on the phenomena, Researchers could state that both learning materials required different attempts and challenges at being implemented. For analyzing the effectiveness of both visual-based and verbal-based materials, I conducted a post-test for the students in both experimental classes. The result of post-test could be seen in the following tables.

Table 2 Post-test score

\begin{tabular}{|c|c|c|c|}
\hline Post-test & Min. & Max. & Mean \\
\hline Group visual-based spatial & 73.75 & 81.75 & 79.08 \\
\hline Group visual-based linguistic & 68.5 & 72.75 & 70.06 \\
\hline Group verbal-based spatial & 67.5 & 81.25 & 75.46 \\
\hline Group verbal-based linguistic & 69.5 & 85.75 & 77.81 \\
\hline
\end{tabular}


Based on the data of the post-test, it could be seen that the score of students in the visual-based class was ranged from 68.5 to 81.75 . The average score for students with spatial learning style raised from 70.39 to 79.08 . The mean score of students with a linguistic learning style had also gained from 62.02 to 70.06. Furthermore, it showed that the post-test score on the verbal-based class was ranged from 69.5 to 85.57 . The average score for students with spatial learning styles had risen from 70.17 to 81.5 . Furthermore, the mean score of students with linguistic learning style gained from 70.78 to 77.81 . According to the result of writing in both experimental classes had different scores. Therefore the students treated with visual-based material had higher achievement than verbal-bases material.

Then, the normality test was examined the data collection of pre-test and post-test. Normality test aims to test wheter in the regresion model, variables have normal distribution or not. A good regression model is having normal or nearnormal data distribution. The normality test was used One-Sample KolmogorovSmirnov Test. The result showed that the significance values of the pre-test score were higher than $0.05(0.200,0.200,0.159,0.200>0.05)$. It means that the data in the pre-test were distributed normally. So, the null hypothesis was accepted. Therefore, it can be concluded that pre-test data of both experimental groups have a normal distribution.

Meanwhile, the result of the normality test of the post-test showed that the significant values of the post-test score were higher than $0.05(0.200,0.169$, $0.200,0.200>0.05)$. It means that the data in the post-test was distributed normally. So, the null hypothesis was accepted. Therefore, it can be concluded that the post-test data of both experimental groups have a normal distribution.

Then, the homogeneity test was used to know whether the data is homogeneous or not. It was as crucial as the normality test because it showed the writing skill similarities between students of experiment class one and those of experiment class two. If the data was not homogeneous, the treatment could not be applied because it means that the groups do not have the same ability to write a text. Here, the homogeneity test was measured using a statistical analysis called the Levene Test of Homogeneity of Variance. 
The homogeneity test of a pre-test for students with spatial and linguistic learning styles showed that the significance score (Sig) was 0.083. Meanwhile, the homogeneity test of the post-test for students with spatial and linguistic learning styles showed that the significance score (Sig) was 0.400. Each of them was higher than the level of significance $(\alpha)=0.05$. As a result, H0 was accepted. Therefore, the pre-test and post-test data for the students with spatial and linguistic learning styles in both experimental groups tend to be homogeneous to answering the research questions this part to be discussed in the hypothesis test. The explanation was as follows.

\section{Discussion}

\section{Teaching Writing Using Visual-based Materials to Students with Spatial Learning Style}

Spatial intelligence involves the potential to recognize and use the patterns of wide space and more confined areas and to form mental images about it. During treatments, the students showed dominant roles of participation in the class. They boldly express their ideas or opinions in formulating the topics they will synthesize in class discussions and group discussions by observing the picture series and videos.

Furthermore, they seemed to have the ability to integrate their ideas into their written works. In responding to the questions or tasks that I gave, they generated a large number of responses. Some responses were unique and unusual. Through visual-based material, I found that they were given chances to explore their ideas and promote them to develop their ability to produce creative writings by using the picture series. Furthermore, I calculated and compared their pre-test and post-test scores. It was shown the different mean scores between them.

The result showed that there was a significant difference between students writing skills in pre-test and post-test. The mean score of the pre-test 70.39 was lower than the mean score of the post-test 79.08. It means that students with spatial learning styles have a high score and showed improvement. The t-value also supported it. T-value was higher than the t-table. It showed that $0.000<0.05$. Therefore, H0 was rejected, and Ha was accepted. It means that using visual- 
based material effectively enhanced the writing skill of students to spatial learning styles.

It was line with Davis in Vitulli, and Giles (2016) argued that since pictures and structured diagrams are more comprehensible than just words and a clearer way to illustrate understanding of complex topics. Furthermore, they seemed to have the ability to integrate their ideas into their written works. In responding to the questions or tasks that the researcher gave, they generated a large number of responses. Some responses were unique and unusual. Through visual-based material, the researcher found that they were given a chance to explore their ideas and promote them to develop their ability to produce creative writing by using the picture series.

\section{Teaching Writing Using Visual-based Materials to Students with Linguistics Learning Style}

Visual-based material promotes students' writing ability, whether they were spatial learning style or linguistic learning style. In delivering treatments to them, the students with spatial learning style showed more significant progress. In sharing ideas, they are often uninhibited in expressing their ideas to their peers in the group discussion. They did not hesitate to represent the opinions of other group members. The mean score of pre-test results of students with spatial learning styles who were taught by visual-based materials was 62.02. While the post-test mean score result for this group showed that there was also a significant improvement, it means that visual-based material was also effective in teaching writing the analytical exposition text for students with a linguistic learning style. The t-value result also supported it. It can be seen that the significant value was 0.000 . It showed that $0.000<0.05$. Therefore, $\mathrm{H} 0$ was rejected, and $\mathrm{Ha}$ was accepted. Visual-based material was more effective than Verbal-based material in teaching writing text for students with a linguistic learning style.

As stated by Chee \& Wong (2013), they say visual media, in particular, are considered as an effective means to support learning since students learn most through the sense of sight (Chee \& Wong 2003). Visual images are not only highly required by the students to help them make meaning but are also relevant and essential to support them in enhancing their academic literacy. However, 
learning conditions sometimes become less controlled when students wait to get directions from teachers. Thus, the students became less enthusiastic about learning even though some benefited tremendously to complete their writing.

Teaching Writing Using Verbal-based Materials to Students with Spatial Learning Style.

In the second experimental class, the implementation of verbal-based material required more effort for the lecturer than visual-based material. It happened because the teacher had to be responsive to students' needs in accomplishing their written texts. Different students' learning styles forced the teacher to be understood, giving a supportive explanation.

Based on the statistical analysis result, the students with spatial learning styles perform different results on their post-test compared to the pre-test. The mean score of the post-test result of the students with spatial learning styles taught by verbal-based material was better than the pre-test score. The significant value was $0.000<0.05$. Data analysis showed that using verbal-based materials effectively enhanced the writing skills of the students with spatial learning styles. Students with spatial learning styles could follow the instructions given to complete their works related to verbal-based material. However, the students with spatial learning styles used their imagination to organize their ideas and develop their writing from the teacher using essay analytical exposition text. In that way, their writing skills could be promoted even if it took a long time in the effort. Regarding the teacher's role in the classroom, the teachers needed more effort in convincing students to be consistent in the learning process. In this study, the teacher grouped students in a homogeneous group according to the topic they wanted to develop in their writings.

As stated by Wright (1989), pictures had an essential role in language learning since pictures contribute to the context, structure, vocabulary, function, and skill in which the language is being used. According to respondents, the best method is a method of assignment, by utilizing media of picture storybooks. Thus, through the media, I could guide students writing development accurately and directed them to produce excellent written works. 
In addition, the research results reported that students who prefer to use spatial learning style learn English better through comprehending and dealing with mental models than writing a paragraph. Thus, teaching material selection and development is important because it increases in-depth knowledge acquired through immersion, allows teachers to use nonlanguage sources.

\section{Teaching Writing Using Verbal-based Materials to Students with Linguistics Learning Style}

Students with linguistic learning syle have advantages in writing a text. It is because Linguistic intelligence involves sensitivity to spoken and written language, the ability to learn languages, and the capacity to use language to accomplish individual goals. This intelligence includes the ability to use language to express oneself rhetorically or poetically adequately; and language as a means to remember information. Students' mean scores before and after treatment showed a significant difference based on the statistical analysis. Their post-test 70.78 was better than pre-test 77.81 . The t-value result also supported it. It can be seen that a significant value is 0.000 . Therefore, Ha was accepted, and H0 was rejected.

Primary students' obstacles in writing were their lack of vocabulary to develop their topic. Soodeh (2012) also holds that the amount of familiar and unfamiliar vocabulary is one of the most significant elements in discerning the compilation of a text. Based on the problem, visual-based and verbal-based teaching materials from the teacher can stimulate and help students in exploring their ideas in writing.

People with linguistic learning styles learn best when taught using spoken or written materials. They prefer activities that are based on language reasoning rather than abstract visual information. Students usually enjoy written projects, speech and drama classes, debate, language classes, and journalism.

\section{Teaching Writing Using Visual-based and Verbal-based Materials to Students with Spatial Learning Style}

The mean score of the post-test mean score in experiment group one (visual-based material) was 79.09, and the post-test mean score in class two (verbal-based material) was 75.47 . It can be concluded that the ratings of students 
who are taught using visual-based material got a higher score than those who were taught using verbal-based material. Although visual-based material had a higher mean score than verbal-based material, it could not indicate that visual-based material was more effective with spatial learning style. Due to the significance value, there were no more effective materials between them. Both materials could improve the students' achievement with different learning styles. In short, there was no significant difference between the students' scores taught through two experimental teaching materials for those with spatial learning style.

The data result concluded that there was no significant difference between visual-based and verbal-based materials in teaching writing the analytical exposition text for students with spatial learning style. To declare the hypothesis, I analyzed the post-test scores of students with spatial learning style at two experimental classes. It was shown the different mean scores between them. The mean score of students with spatial learning style taught by visual-based material was higher than verbal-based material. Subsequently, a differential test was performed to make sure the significance value. According to the result, the significance value showed 0.56 . The value was higher than 0.05 . Therefore, the hypothesis was rejected.

\section{Teaching Writing Using Visual-based and Verbal-based Materials to Students with Linguistic Learning Style}

The mean score of the post-test mean score in class 1(visual-based material) was 70.06, and the post-test mean score in class 2 (verbal-based material) was 77.81. It can be concluded that the score of students who taught by using verbal-based material got a higher score than those who taught by using visual-based material.

The next result was concluded that verbal-based material was more effective than visual-based material in teaching writing analytical exposition text for students with a linguistic learning style. To prove the hypothesis, I analyzed the post-test scores of students with linguistic learning style at two experimental classes. It was shown the different mean scores between them. The mean score of students with linguistic learning styles taught by verbal-based material was higher than visual-based material. Then, a differential test was performed to make sure 
the significance value. According to the result, the significance value showed 0.000 . The value was less than 0.05 . Therefore, the hypothesis was accepted.

I was referring to the sig. The value of this analysis could be concluded that verbal-based material was more effective than visual-based material in teaching writing analytical exposition text for students with linguistics learning styles. In short, there was a significant difference between the students' scores taught by using visual-based and verbal-based material with a linguistic learning style.

\section{The Interaction Effect among Material, Students' Learning Style, and Writing Skill}

For analyzing the interaction among variables in this research, I performed $2 \times 2$ factorial designs with Analysis of Variance. The analysis of interaction among teaching materials and students' learning styles was carried out towards the students' achievements in writing tests. There were several procedures to show that interaction.

From the calculation, the significant value of 0.000 was less than 0.05 . It means that there was interaction among visual and verbal based materials, students' learning styles, and writing skills. This was performed to find out the significant relationship between independent and dependent variables in this research. Thus, the considerable effect of the implementation of visual-based and verbal-based materials on students' achievement could be declared. After that, the connection between students' learning styles and their writing achievement was analyzed. The result depicted the significant effect of learning styles on writing achievement. Students with spatial learning style could achieve higher scores in writing test. In the last statement, this present study has proven that visual-based and verbal-based materials could be implemented in teaching writing the analytical exposition text for students with different learning styles. They are also able to increase students' achievement in writing.

\section{CONCLUSION AND SUGGESTION}

The results showed that visual-based material was useful in teaching writing the analytical exposition text for both student groups. It was obtained by calculating the significant difference between students' pre-test and post-test 
scores to prove that statement. Then, the comparison of two student groups taught by visual-based material was analyzed to determine the difference in achievement. The result showed that there was substantially different. Visual-based material was more effective in teaching writing the analytical exposition text for students with spatial learning styles. Furthermore, the analysis of the effectiveness of verbal-based material to teach writing the analytical exposition text for students with both spatial and linguistic learning styles was drawn. They showed that verbal-based material was adequate to be implemented in teaching writing the analytical exposition text for both students with spatial and linguistic learning styles.

Thus, this material was effective in teaching writing the analytical exposition text for students with both spatial and linguistic learning styles. After that, the comparison between two groups taught verbal-based material was found that there was a significant difference among them in which this material was more effective for students whose linguistic learning style. The subsequent results indicated that both visual-based and verbal-based materials could significantly improve students' writing analytical exposition text with different learning styles. The significant difference between them could not decide the more practical material. Consequently, there was no more effectual material of teaching writing for students with spatial learning style. Another result of using both materials to students with linguistic learning styles suggested that verbal-based material could be said to be more effective than visual-based material in teaching writing analytical exposition text.

The last result of this research referred to the interaction among teaching materials, visual-based and verbal-based materials, and students' learning styles towards students' writing achievement. The first result demonstrated that teaching materials could influence students' writing. Similarly, students' learning styles also had real causes for their writing abilities.

In light of the results, The author presents suggestions theoretically, practically, and pedagogically. Theoretically, this study expects to be an input for the institution in planning, designing, and developing the English curriculum. Practically, this study expects to contribute to English teachers to show them that 
visual-based and verbal-based materials teach English, especially in writing skills. Pedagogically, this study expects to give the English lecturer useful contributions and information to revise their techniques and media in teaching writing to all students.

\section{ACKNOWLEDGEMENT}

This paper was fully supported by the Directorate of Research and Community Service, Directorate General of Strengthening Research and Development of the Ministry of Research, Technology, and Higher Education through the 2020 Beginner Lecturer Research Program.

\section{REFERENCES}

Amir, Ruslin \& Jelas, Zalizan \& Rahman, Saemah. 2011. Learning Styles of University Students: Implications for Teaching and Learning. World Applied Sciences Journal 14 (Special Issue of Innovation and Pedagogy for Diverse Learners), 22-26, 2011

Bagheri, V. 2015. The Impact of Visual and Verbal Techniques on Vocabulary Achievement of Iranian High School Students. Advances in Asian Social Science, 6(4), 107-108

Chee, T. S. and Wong, A. F. L. 2003. Teaching and learning with technology: An Asia-Pacific perspective. Prentice Hall: Pearson Education Asia.

Fayombo, G. 2015. Learning Styles, Teaching Strategies and Academic Achievement among some Psychology Undergraduates in Barbados. Caribbean Educational Research Journal, 3(2), 46-61.

Fardon, M. 2013. Relationships between students' learning style preference and exam achievement in differing forms of assessment during an advanced apprenticeship at a vocational Further Education College. Institute of Learning, Department of Education, University of Oxford.

Fleming, N. 2012. Teaching and Learning Style: VARK Strategies. USA: Springfield.

Fraenkl, J. R., \& Wallen, N. E. 2005. How to Design and Evaluate Research in Education. Mcgraw - Hill, Inc: Singapore.

Gilakjani, A. P. 2012. Visual, Auditory, Kinaesthetic Learning Styles and Their Impacts on English Language Teaching. Journal of Studies in Education, 2(1), 104-113.

Hyland, K. 2003. Second Language Writing. United States of America: Cambridge University Press 
Hussain, Nasreen \& Ayub, Nadia. 2012. Learning Styles of Students and Teaching Styles of Teachers in Business Education: A Case Study of Pakistan. Procedia - Social and Behavioral Sciences. 69 (2012) 1737 1740 ISSN 1818-4952

Macwan, H. J. 2015. Using visual aids as authentic material in ESL classrooms. Research Journal of English Language and Literature,3(1), 91-96. Available at: http://www.rjelal.com

Nunan, D. 2003. Practical English Language Teaching. New York: McGraw-Hill.

O'Brien, L. 1990. Learning channel preference checklist. Rockville, MD: Specific Diagnostic Services.

Ontario. 2005. A guide to Effective Instruction in Writing: Kindergarten to Grade 3. Toronto: Ontario Education.

Singh, T. 2016. Learning styles. The National medical journal of India. 29. 181182.

Soleimani, Y. 2014. The Affirmative Impact of Visual and Verbal Techniques upon Raising Vocabulary Achievement of Iranian High School Students. International Journal of Language Learning and Applied Linguistics World, 7(4), 130-144. Retrieved from: http://www.ijllalw.org/finalversion7411.pdf

Soodeh H. M, Zaidah Z. and Mahsa G. 2012. A Review on the Important Role of Vocabulary Knowledge in Reading Comprehension Performance. The 8th International Language for Specific Purposes (LSP) Seminar - Aligning Theoretical. Procedia - Social and Behavioral Sciences 66 ( 2012 ) 555 563.

Vitulli, P., \& Giles, R. 2016. Mind Mapping : Making Connections with Images and Color. Delta Journal of Education, 6(2), 1-10.

Vizeshfar, Fatemeh \& Torabizadeh, Camellia. 2017. The effect of teaching based on dominant learning style on nursing students' academic achievement. Nurse Education in Practice. 28. 10.1016/j.nepr.2017.10.013.

Wright, A. 1989. Picture for language learning. New York: Cambridge University Press. 